\title{
ANALISIS PENDUGAAN UKURAN KEMISKINAN MONETER PADA CONTOH BERUKURAN KECIL
}

\author{
Nurul Hidayati ${ }^{1 *}$, Asep Saefuddin ${ }^{2)}$, Anang Kurnia ${ }^{2)}$ \\ ${ }^{1)}$ Statistika, Fakultas Matematika dan Ilmu Pengetahuan Alam, Universitas Bengkulu, \\ Bengkulu, 65114 \\ ${ }^{2)}$ Statistika, Fakultas Matematika dan Ilmu Pengetahuan Alam, Institut Pertanian Bogor, \\ Bogor, 16680 \\ *noe_o3l@yahoo.com
}

\begin{abstract}
Abstrak
Kemiskinan merupakan sebagian dari masalah pembangunan yang berkaitan dengan berbagai dimensi yang meliputi sosial, ekonomi, budaya, politik, regional dan waktu.Penelitian ini bertujuan untuk menilai ukuran sampel dari ukuran kemiskinan moneter yang digunakan oleh Badan Pusat Statistik Indonesia (BPS) dan juga untuk mencari solusi alternatif dalam mengestimasi ukuran kemiskinan moneter dalam contoh berukuran kecil. Metode yang digunakan dalam penelitian ini adalah estimasi langsung yang dilengkapi dengan simulasi yang bertujuan untuk mengevaluasi ukuran sampel dalam perhitungan estimasi pengukuran kemiskinan dan Bayes empiris sebagai solusi alternatif dalam mengestimasi ukuran kemiskinan moneter dengan ukuran sampel kecil. Hasil penelitian ini menunjukkan nilai estimasi memiliki varians kecil dan tidak bias jika ukuran sampel yang digunakanbesar, dan sebaliknya. Ini terbukti dalam perbandingan ukuran sampel, seperti yang ditunjukkan padaperilaku indeks bias Relative Bias (RB), Absolute Relative Bias, dan Relative Mean Square Error (RMSE). Dengan demikian, estimasi langsung dapat dikoreksi dengan estimasi Bayesian empiris dalam menangani masalah ukuran sampel yang kecil.
\end{abstract}

Kata Kunci: indikator kemiskinan, pendugaan langsung, Bayes empiris, indeks perilaku

\section{PENDAHULUAN}

Kemiskinan merupakan sebagian dari masalah pembangunan yang berkaitan dengan berbagai dimensi yang meliputi sosial, ekonomi, budaya, politik, regional dan waktu.Kemiskinan didefinisikan sebagai keadaan masyarakat yang berada pada suatu kondisi yang serba terbatas, baik keterbatasan dalam aksebilitas pada faktor produksi, peluang atau kesempatan berusaha, pendidikan, maupun fasilitas hidup lainnya, sehingga dalam setiap aktivitas maupun usaha menjadi sangat terbatas pula (Mafruhah, 2009:1).

Di sisi lain, perlu dipahami bahwa strategi penanggulangan kemiskinan 
membutuhkan ketersediaan data kemiskinan yang akurat dan tepat sasaran. Pengukuran kemiskinan dapat menjadi instrumen bagi pengambil kebijakan dalam memfokuskan perhatian pada kondisi hidup orang miskin.

Terdapat dua pendekatan untuk mengukur kemiskinan, yaitu pendekatan nonmoneter dan pendekatan moneter. Pada pendekatan nonmoneter, konsep kesejahteraan dilihat dalam bentuk pencapaian atas keberhasilan dari individu dan rumah tangga. Dengan demikian indikator yang digunakan dalam pendekatan nonmoneter adalah indikator yang melekat pada individu dan rumah tangga (Abdillah, 2011:30). Sedangkan pada pendekatan moneter,kesejahteraan diukur dari total konsumsi (kalori) yang dinikmati individu. Sehingga, menurut Rozuli (2012:1) indikator yang digunakan dalam pendekatan moneter adalah pendapatan dan pengeluaran konsumsi per kapita rumah tangga.

Konsep kemiskinan yang digunakan oleh Badan Pusat Statistik (BPS) adalah pendekatan moneter, dengan mendefinisikan kemiskinan sebagai ketidakmampuan untukmemenuhi standar tertentu dari kebutuhan dasar, baik makanan maupun bukan makanan (BPS, 2008:29). Kebutuhan dasar ini diukur berdasarkan pengeluaran, dalam bentuk pengeluaran per kapita per bulan rumah tangga. Penduduk yang memiliki rata-rata pengeluaran per kapita per bulan di bawah garis kemiskinan dikategorikan sebagai penduduk miskin (BPS, 2008:32).

\section{Fosteret.al}

mengembangkan ukuran kemiskinan yang dikenal dengan rumus Foster Greer $\mathrm{T}$ horbecke (FGT) yaitu (1) persentase penduduk miskin (Head Count Index (HCI), berada di bawah Garis Kemiskinan (GK), (2) indeks kedalaman kemiskinan (Poverty Gap Index (PGI), $\mathrm{P}_{1}$ ) adalah rata-rata kesenjangan pengeluaran masing-masing penduduk miskin terhadap garis kemiskinan, semakin tinggi indeks maka semakin jauh rata-rata pengeluaran penduduk dari garis kemiskinan dan (3) indeks keparahan kemiskinan (Distributionally Sensitive Index (DSI), $\mathrm{P}_{2}$ ) adalah gambaran penyebaran pengeluaran diantara penduduk miskin, semakin tinggi nilai indeks maka semakin tinggi ketimpangan pengeluaran diantara penduduk miskin.

Perhitungan pendugaan ukuran kemiskinan moneter dilakukan BPS secara langsung berdasarkan data Survei Sosial Ekonomi Nasional (Susenas). Pendugaan langsung ini tidak mampu memberikan ketelitian yang baik jika ukuran contoh kecil, sehingga statistik yang diperoleh akan memiliki ragam yang besar dan akurasi yang rendah. Selain itu, pendugaan tidak dapat dilakukan karena contoh yang tidak terwakili di dalam survei. Hal ini dapat diatasi dengan menggunakan suatu metode pendugaan area kecil untuk meningkatkan efektifitas ukuran contoh dengan cara menambahkan informasi pada area tersebut dari area lain atau sumber informasi lain melalui pembentukan model yang tepat.

Pendugaan parameter kemiskinan moneter saat ini dirasakan sangat penting seiring dengan berkembangnya otonomi daerah untuk mendapatkan informasiinformasi pada level kabupaten/kota, kecamatan, bahkan kelurahan atau desa. Informasi-informasi tersebut dapat digunakan untuk pedoman dalam menyusun sistem perencanaan, pemantauan, dan kebijakan daerah lainnya tanpa harus mengeluarkan biaya yang besar untuk mengumpulkan data sendiri. Namun 
demikian, ada suatu permasalahan yang ditemui dalam pendugaan parameter kemiskinan moneter untuk wilayah administrasi di bawah kabupaten/kota, yaitu pengamatan survei (dalam hal ini Susenas) memiliki ukuran contoh yang kecil.

Elbers, Lanjouw dan Lanjouw (ELL) (2003:355) mengusulkan suatu metode pendugaan area kecil yang telah diterapkan oleh Bank Dunia dalam pemetaan kemiskinan yang mengasumsikan satuan model level dari kombinasi data sensus dan survei. Haslett et. al (2010:157) membandingkan teknik-teknik regresi survei untuk menentukan model yang cocok pada pendugaan kemiskinan area kecil dalam metode ELL. Proyek EURAREA yang dilakukan di Eropa mengembangkan metode pendugaan karakteristik pendapatan area kecil yang terbatas pada parameter linier. Metode tersebut berdasarkan pada aplikasi model campuran yang menggunakan informasi tambahan untuk mendefinisikan penduga-penduga dalam area kecil (Saei dan Chambers, 2003:2).

Tulisan ini akan membahas karakteristik nilai dugaan ukuran kemiskinan moneter dengan menggunakan metode pendugaan langsung dan pemecahan masalah pendugaannya dengan mengadopsi metode yang diajukan oleh Molina dan Rao (2010). Lebih rinci tulisan ini akan membahas tentang pengaruh ukuran contoh pada pendugaan ukuran kemiskinan moneter yang digunakan oleh BPS dan solusi alternatif pendugaan ukuran kemiskinan moneter pada saat ukuran contoh kecil.

Tulisan ini akan memaparkan hasil simulasi metode pendugaan langsung yang dievaluasi menggunakan relative bias, absolute relative bias, dan relative mean square error serta metode yang disarankan diaplikasikan pada data susenas untuk wilayah

administrasi

di

bawah kabupaten/kota dengan ukuran contoh kecil.

Berkenaan dengan kemiskinan, Fosteret.al (1984:763) merumuskan tiga ukuran kemiskinan, yaitu indeks kemiskinan $\left(\mathrm{P}_{0}\right)$, indeks kedalaman kemiskinan $\left(\mathrm{P}_{1}\right)$ dan indeks keparahan kemiskinan $\left(\mathrm{P}_{2}\right)$. Tiga ukuran kemiskinan ini juga dikenal sebagai ukuran kemiskinanFGT (Foster, Greer, dan Thorbecke). Molina dan Rao (2010) mengembangkan ukuran kemiskinan FGT sebagai berikut :

$$
\mathrm{P}_{\alpha \mathrm{i}}=\frac{1}{\mathrm{~N}_{\mathrm{i}}} \sum_{\mathrm{j} \in \mathrm{S}_{\mathrm{i}}} \mathrm{P}_{\alpha \mathrm{ij}} \quad \mathrm{i}=1, \ldots, \mathrm{m}
$$

didefinisikan dengan:

$$
\begin{aligned}
& P_{\alpha i j}=\left(\frac{z-R_{i j}}{z}\right)^{\alpha} I\left(R_{i j}<z\right), \\
& j=1,2, \ldots, N_{i} ; \alpha=0,1,2
\end{aligned}
$$

$$
\begin{aligned}
\mathrm{z} & =\text { Garis kemiskinan } \\
\mathrm{R}_{\mathrm{ij}} & =\begin{array}{l}
\text { Rata-rata pengeluaran } \\
\text { perkapita rumah tangga } \\
\text { sebulan }
\end{array} \\
\mathrm{N}_{\mathrm{i}} & =\text { Jumlah rumah tangga }
\end{aligned}
$$

serta $I\left(R_{i j}<z\right)=1$ jika $R_{i j}<z$ (rumah tangga yang dikategorikan miskin) dan $\mathrm{I}\left(\mathrm{R}_{\mathrm{ij}}<\mathrm{z}\right)=0$ jika $\mathrm{R}_{\mathrm{ij}}>\mathrm{z}$ (rumah tangga yang dikategorikan tidak miskin). Jika $\alpha=0$, diperoleh indeks kemiskinan $\left(\mathrm{P}_{0}\right)$, jika $\alpha=1$ diperoleh indeks kedalaman kemiskinan $\left(\mathrm{P}_{1}\right)$ dan jika $\alpha=2$ disebut indeks keparahan kemiskinan $\left(\mathrm{P}_{2}\right)$.

Penduga langsung dari ukuran kemiskinan FGT untukwilayahke - iadalah

$$
\begin{gathered}
\hat{\mathrm{P}}_{\alpha \mathrm{i}}=\frac{1}{\mathrm{n}_{\mathrm{i}}} \sum_{\mathrm{j} \in \mathrm{S}_{\mathrm{i}}} \mathrm{P}_{\alpha i \mathrm{j}}, \\
\alpha=0,1,2 ; \mathrm{i}=1,2, \ldots, \mathrm{m}
\end{gathered}
$$


Jika $_{\mathrm{ij}}$ adalah pembobot survei untuk setiap contoh, maka penduga langsung untuk $\mathrm{P}_{\alpha \mathrm{i}}$ adalah

$$
\begin{gathered}
\hat{\mathrm{P}}_{\alpha \mathrm{i}}^{\mathrm{w}}=\frac{1}{\widehat{\mathrm{N}}_{\mathrm{i}}} \sum_{\mathrm{j} \in \mathrm{S}_{\mathrm{i}}} \mathrm{w}_{\mathrm{ij}} \mathrm{P}_{\alpha \mathrm{ij}}, \\
\alpha=0,1,2 ; \mathrm{i}=1,2, \ldots, \mathrm{m}
\end{gathered}
$$

dengan $\widehat{\mathrm{N}}_{\mathrm{i}}=\sum_{\mathrm{j} \in \mathrm{S}_{\mathrm{i}}} \mathrm{W}_{\mathrm{ij}}$ adalah penduga tak bias bagi $\mathrm{N}_{\mathrm{i}}$ dan $\mathrm{w}_{\mathrm{ij}}$ adalah bobot satuan contoh ke-j dari wilayah ke-i.Jika ukuran contoh yang dipilih dari wilayah ke-isangat kecil atau kejadiannya nol, maka penduga langsung (3) atau (4) tidak tepat digunakan.

Pendugaan Bayes empirik bagi ukuran kemiskinan $\mathrm{P}_{\alpha i}$, yaitu (Molina dan Rao, 2010:372-374):

$$
\widehat{\mathrm{P}}_{\alpha \mathrm{i}}^{\mathrm{EB}}=\frac{1}{\mathrm{~N}_{\mathrm{i}}}\left\{\sum_{\mathrm{j} \in \mathrm{s}_{\mathrm{i}}} \mathrm{P}_{\alpha \mathrm{ij}}+\sum_{\mathrm{j} \in \mathrm{r}_{\mathrm{i}}} \hat{\mathrm{P}}_{\alpha \mathrm{ij}}^{\mathrm{EB}}\right\}
$$

untuk memperoleh nilai penduga dari Bayes empirik $\left(\widehat{\mathrm{P}}_{\text {aij }}^{\mathrm{EB}}\right)$ digunakan model regresi linier tersarang. Model ini berhubungan secara linier untuk semua area, peubah populasi $\mathrm{Y}_{\mathrm{ij}}$ ditransformasi ke vektor $\mathbf{x}_{\mathrm{ij}}$ yang mengandung nilai dari peubah penjelas $\mathrm{p}$ dan termasuk sebuah pengaruh khusus area acaku $_{\mathrm{i}}$ dan memiliki galat $\mathrm{e}_{\mathrm{ij}}$ (Molina dan Rao, 2010:374):

$$
\begin{gathered}
Y_{i j}=\mathbf{x}_{i j}^{\prime} \boldsymbol{\beta}+u_{i}+e_{i j}, \\
j=1, \ldots, N_{i}, \quad i=1, \ldots, m \\
u_{i} \sim N\left(0, \sigma_{u}^{2}\right), e_{i j} \sim N\left(0, \sigma_{e}^{2}\right)
\end{gathered}
$$

dengan pengaruh area $u_{i}$ dan galat $e_{i j}$ saling bebas. Misalkan didefinisikan vektor dan matriks yang diperoleh dengan stacking element untuk area $\mathrm{i}$ :

$\mathbf{y}_{\mathrm{i}}=\underset{1 \leq \mathrm{j} \leq \mathrm{N}_{\mathrm{i}}}{\operatorname{col}}\left(\mathrm{Y}_{\mathrm{ij}}\right), \mathrm{e}_{\mathrm{i}}=\underset{1 \leq \mathrm{j} \leq \mathrm{N}_{\mathrm{i}}}{\operatorname{col}}\left(\mathrm{e}_{\mathrm{ij}}\right), \mathbf{X}_{\mathrm{i}}=\underset{1 \leq \mathrm{j} \leq \mathrm{N}_{\mathrm{i}}}{\operatorname{col}}\left(\mathrm{x}_{\mathrm{ij}}^{\prime}\right)$
Kemudian vektor $\mathbf{y}_{\mathrm{i}}, \mathrm{i}=1, \ldots, \mathrm{m}$ saling bebas dengany $\mathbf{y}_{\mathrm{i}} \sim \mathrm{N}\left(\boldsymbol{\mu}_{\mathrm{i}}, \mathrm{V}_{\mathrm{i}}\right)$, dengan:

$$
\begin{aligned}
& \boldsymbol{\mu}_{\mathrm{i}}=\mathrm{X}_{\mathrm{i}} \boldsymbol{\beta} \text { dan } \\
& \mathbf{V}_{\mathrm{i}}=\sigma_{\mathrm{u}}^{2} \mathbf{1}_{\mathrm{N}_{\mathrm{i}}} \mathbf{1}_{\mathrm{N}_{\mathrm{i}}}^{\prime}+\sigma_{\mathbf{e}}^{2} \mathbf{I}_{\mathrm{N}_{\mathrm{i}}}
\end{aligned}
$$

Dengan $\mathbf{1}_{\mathrm{k}}$ dinotasikan sebuah vektor kolom dari sesuatu yang berukuran $\mathrm{k}$ dan $\mathbf{I}_{\mathrm{k}}$ adalah matriks identitas $\mathrm{k} \mathrm{x} \mathrm{k}$.

Misalkan penguraian dari $\mathbf{y}_{i}$ adalah anggota contoh dan bukan anggota contoh $\mathbf{y}_{\mathrm{i}}=\left(\mathbf{y}_{\mathrm{is}}^{\prime}, \mathbf{y}_{\mathrm{ir}}^{\prime}\right)^{\prime}$ dengan $\mathrm{n}_{\mathrm{i}}>0$, dan penguraian yang bersesuaian dari $x_{i}, \mu_{i}$, dan $\mathbf{V}_{\mathbf{i}}$. Sehingga sebaran dari $\mathbf{y}_{\mathbf{i r}}$ bersyarat $\mathbf{y}_{\mathbf{i s}}$ adalah:

$$
\mathbf{y}_{\text {ir }} \mid \mathbf{y}_{\text {is }} \sim N\left(\mu_{\text {ir } \mid \mathrm{s}}, \mathrm{V}_{\text {ir } \mid \mathrm{s}}\right)
$$

dengan:

$$
\begin{aligned}
& \boldsymbol{\mu}_{\mathrm{ir} \mid \mathrm{s}}=\mathbf{X}_{\mathrm{ir}} \boldsymbol{\beta}+\sigma_{\mathrm{u}}^{2} \mathbf{1}_{\mathrm{N}_{\mathrm{i}}-\mathrm{n}_{\mathrm{i}}} \mathbf{1}_{\mathrm{n}_{\mathrm{i}}}^{\prime} \mathbf{V}_{\mathrm{is}}^{-\mathbf{1}}\left(\mathbf{y}_{\mathrm{is}}-\mathbf{X}_{\mathrm{is}}\right. \\
& \mathbf{V}_{\mathrm{ir} \mid \mathrm{s}}=\sigma_{\mathrm{u}}^{2}\left(1-\gamma_{\mathrm{i}}\right) \mathbf{1}_{\mathrm{N}_{\mathrm{i}}-\mathrm{n}_{\mathrm{i}}} \mathbf{1}_{\mathrm{N}_{\mathrm{i}}-\mathrm{n}_{\mathrm{i}}}^{\prime}+\sigma_{\mathrm{e}}^{2} \mathbf{I}_{\mathrm{N}_{\mathrm{i}}-\mathrm{n}}
\end{aligned}
$$

untuk

$\mathrm{V}_{\mathrm{is}}=\sigma_{\mathrm{u}}^{2} \mathbf{1}_{\mathbf{n}_{\mathbf{i}}} \mathbf{1}_{\mathrm{n}_{\mathrm{i}}}^{\prime}+\sigma_{\mathbf{e}}^{2} \mathbf{I}_{\mathbf{n}_{\mathbf{i}}}$ dan $\gamma_{\mathrm{i}}=\sigma_{\mathrm{u}}^{2}\left(\sigma_{\mathrm{u}}^{2}+\frac{\sigma_{\mathrm{e}}^{2}}{\mathrm{n}_{\mathrm{i}}}\right)^{-1}$. Jika diasumsikan bahwa partisi $\mathbf{y}_{\mathrm{i}}(\mathrm{i}=1, \ldots, \mathrm{m})$ dari $\Omega_{\mathrm{i}}$ ke $\mathrm{s}_{\mathrm{i}}$ dan $\mathrm{r}_{\mathrm{i}}$ diketahui serta peubah penjelas $\mathbf{x}_{\mathrm{ij}}$ diketahui berhubungan dengan $\mathrm{j} \epsilon \mathrm{r}_{\mathrm{i}}$, maka $\mathbf{y}_{\text {ir }} \mid \mathbf{y}_{\text {is }}$ dan $\mathbf{y}_{\text {ir }} \mid \mathbf{y}_{\mathrm{s}}$ akan mempunyai sebaran yang sama.

Selanjutnya, Molina dan Rao (2010:375) menyatakan bahwa pendekatan Monte Carlo dilakukan dengan mensimulasi $m$ buah vektor $\boldsymbol{y}_{\text {ir }}$ yang berukuran $\mathrm{N}_{\mathrm{i}}-\mathrm{n}_{\mathrm{i}}$, $\mathrm{i}=1, \ldots, \mathrm{m} \quad$ dengan sebaran $\mathbf{y}_{\text {ir }} \mid \mathbf{y}_{\text {is }} \sim N\left(\mu_{\text {ir } \mid \mathrm{s}}, V_{\text {ir } \mid \mathrm{s}}\right)$. Simulasi ini diulang sebanyak Lkali. Namun, simulasi ini tidak dapat dikerjakan dengan mudah jika $\mathrm{N}_{\mathrm{i}}$ besar. Adapun prosedur yang dapat digunakan untuk mengatasi persoalan ini 
adalah membangkitkan $y_{\text {ir }}$ dengan menggunakan model berikut:

$$
\mathrm{y}_{\mathrm{ir}}=\mu_{\mathrm{ir} \mid \mathrm{s}}+\mathrm{v}_{\mathrm{i}} \mathbf{1}_{\mathrm{N}_{\mathrm{i}}-\mathrm{n}_{\mathrm{i}}}+\boldsymbol{\epsilon}_{\mathrm{ir}}
$$

dengan matriks $V_{\text {ir|s }}(10)$ bersesuaian dari matrik kovarian $\mathbf{y}_{\text {ir }}$. Pengaruh peubah acak yang baru $v_{\mathrm{i}}$ dan galat $\boldsymbol{\epsilon}_{\text {ir }}$ yang saling bebas dan memenuhi:

$$
\begin{aligned}
& v_{\mathrm{i}} \sim N\left(0, \sigma_{v}^{2}\left(1-\gamma_{\mathrm{i}}\right)\right), \mathrm{i}=1, \ldots, \mathrm{m} \\
& \epsilon_{\mathrm{ir}} \sim \mathrm{N}\left(0_{\mathrm{N}_{\mathrm{i}}}, \sigma_{\mathrm{e}}^{2} \mathbf{I}_{\mathrm{N}_{\mathrm{i}}-\mathrm{n}_{\mathrm{i}}}\right) .
\end{aligned}
$$

dan

Persamaan (11) digunakan untuk membangun vektor normal ganda $y_{i r}$, untuk $\mathrm{j} \in \mathrm{r}_{\mathrm{i}}$. Seperti yang dijelaskan sebelumnya parameter model $\boldsymbol{\theta}=\left(\beta^{\prime}, \sigma_{\mathrm{u}}^{2}, \sigma_{\mathrm{e}}^{2}\right)^{\prime}$ yang diduga dari $\hat{\boldsymbol{\theta}}=\left(\widehat{\boldsymbol{\beta}}^{\prime}, \widehat{\sigma}_{\mathrm{u}}^{2}, \widehat{\sigma}_{\mathrm{e}}^{2}\right)^{\prime}$ dan peubah $\mathbf{y}_{\text {ir }}$ dibangun dari pendugaan sebaran normal yang bersesuaian.

\section{METODE PENELITIAN}

\section{Data}

Penelitian ini menggunakan dua jenis data, yaitu data simulasi dan data terapan. Data simulasi diperoleh dengan melakukan simulasi data yang mengikuti sebaran tertentu, dalam hal ini sebaran $\log \mathrm{Y} \sim \mathrm{N}\left(\mu, \sigma^{2}\right)$. Data aplikasi diperoleh dari dari data Susenas dan data PODES Provinsi Jawa Timur tahun 2008. Kedua jenis data dimaksud dapat dijelaskan seperti berikut ini :

\section{Data Pendekatan Simulasi}

Data pendekatan simulasi dalam penelitian ini digunakan untuk mengevaluasi pengaruh ukuran contoh terhadap perhitungan pendugaan langsung ukuran kemiskinan. Simulasi dilakukan dengan cara membangkitkan data pengamatan (observasi) berukuran 10.000 untuk 9 (sembilan) skenario. Data simulasi yang dibangkitkan berdasarkan pola sebaran data $\log \mathrm{Y} \sim \mathrm{N}\left(\mu, \sigma^{2}\right)$, karena pola sebaran log normal mengakomodir bentuk dari karakteristik pengeluaran per kapita di Provinsi Jawa Timur. Data simulasi dibangkitkan dengan menggunakan fungsi rlnorm pada perangkat lunak program Rstudio. Dari data populasi yang telah diperoleh diambil secara acak data contoh berukuran $5,10,15,20,25,30,40$, $60,80,100,150,200,250$, dan 300 , masingmasing sebanyak 500 kali ulangan.

\section{Data Pendekatan Terapan}

Pendekatan terapan menggunakan dua sumber data, yaitu data Survei Sosial Ekonomi Nasional (Susenas) 2008 dan data Potensi Desa (PODES) 2008 Propinsi Jawa Timur. Dari data Susenas 2008 diambil dua peubah, yaitu data pengeluaran per kapita rumah tangga sebagai peubah respon $\left(Y_{\mathrm{ij}}\right)$ dan data jumlah desa yang memiliki status kelurahan sebagai peubah penjelas untuk rumah tangga anggotacontoh $\left(\mathrm{X}_{\mathrm{is}}\right)$. Data Potensi Desa (PODES) 2008 yang digunakan sebagai sumber data pendukung adalah data proporsi desa yang berstatus kelurahan dari setiap kecamatan. Data ini digunakan sebagai peubah penjelas untuk rumah tangga yang bukan anggota $\operatorname{contoh}\left(\mathrm{X}_{\mathrm{ir}}\right)$.

\section{Metode Analisis}

\section{Pendekatan Simulasi}

Tahap I : Membangkitkan data

Membangkitkan data dengan menggunakan sebaran lognormal $\log \mathrm{Y} \sim \mathrm{N}\left(\mu, \sigma^{2}\right)$ berukuran $\mathrm{N}=10.000, \overline{\mathrm{z}}=185000$ ( $\overline{\mathrm{z}}$ benilai tetap untuk setiap skenario) merupakan nilai rata-rata garis kemiskinan dari 38 kabupaten/kota di Propinsi Jawa Timur dan parameter hasil kombinasi yang tertera pada tabel 1. Gugus data bangkitan ini selanjutnya disebut skenario. 
Tabel 1. Kombinasi Nilai Rataan $(\mu)$, Simpangan Baku $(\sigma)$, dan $E(Y)=355.045$

\begin{tabular}{ccc}
\hline Skenario & $\boldsymbol{\mu}$ & $\boldsymbol{\sigma}$ \\
\hline 1 & 12,6 & 0,6 \\
2 & 11,8 & 1,4 \\
3 & 11,5 & 1,6 \\
4 & 9,9 & 2,4 \\
5 & 9,4 & 2,6 \\
6 & 7,0 & 3,4 \\
7 & 6,3 & 3,6 \\
8 & 3,1 & 4,4 \\
9 & 2,2 & 4,6 \\
\hline
\end{tabular}

Tahap II : Menghitung nilai $\mathrm{P}_{0}, \mathrm{P}_{1}$, dan $\mathrm{P}_{2}$ dari data skenario dengan persamaan berikut:

$$
\begin{aligned}
& P_{\alpha i}=\frac{1}{N_{i}} \sum_{j \in S_{i}} P_{\alpha i j} \quad i=1, \ldots, m ; j=1,2, \ldots, \\
& N_{i} ; \alpha=0,1,2
\end{aligned}
$$

Tahap III : Mengevaluasi nilai pendugaan langsung

Dari data yang telah dibangkitkan pada tahap I, selanjutnya dilakukan analisis untuk mengevaluasi nilai duga dari pendugaan langsung. Evaluasi pendugaan dilakukan dengan tiga metode evaluasi pendugaan yaitu: relative bias (RB), absolute relative bias $(A R B)$, relative means square error (RMSE). Persamaan yang digunakan adalah sebagai berikut :

$$
\begin{aligned}
& R B=\frac{1}{\mathrm{~B}} \sum_{\mathrm{B}=1}^{500}\left(\frac{\widehat{\mathrm{P}}_{\alpha}^{(\mathrm{B})}-\mathrm{P}_{\alpha}}{\mathrm{P}_{\alpha}}\right) \times 100 \%, \alpha=0,1,2 \\
& A R B=\frac{1}{\mathrm{~B}} \sum_{\mathrm{B}=1}^{500}\left|\frac{\widehat{\mathrm{P}}_{\alpha}^{(\mathrm{B})}-\mathrm{P}_{\alpha}}{\mathrm{P}_{\alpha}}\right| \times 100 \%, \alpha=0,1,2 \\
& R M S E=\frac{1}{\mathrm{~B}} \sum_{\mathrm{B}=1}^{500}\left(\frac{\widehat{\mathrm{P}}_{\alpha}^{(\mathrm{B})}-\mathrm{P}_{\alpha}}{\mathrm{P}_{\alpha}}\right)^{2} \times 100 \%, \alpha=0,1,2
\end{aligned}
$$

Tahap IV : Membandingkan keempat ukuran evaluasi penduga parameter yang diperoleh dari tahap III pada penggunaan ukuran contoh yang berbeda.

\section{Pendekatan Terapan}

Langkah-langkah yang dilakukan pada data aplikasi adalah sebagai berikut:

1. Eksplorasi data dan menentukan bentuk sebaran dari peubah Y (pengeluaran per kapita).

2. Menghitung nilai duga ukuran kemiskinan $\mathrm{P}_{0}, \mathrm{P}_{1}$, dan $\mathrm{P}_{2}$ untuk tingkat Kabupaten/Kota menggunakan persamaan (1).

3. Menghitung nilai duga ukuran kemiskinan $\mathrm{P}_{0}, \mathrm{P}_{1}$, dan $\mathrm{P}_{2}$ untuk tingkat kecamatan di Kabupaten Kota Malang di Provinsi Jawa Timur menggunakan persamaan (1).

4. Mengulangi langkah 3 dengan mengadopsi metode yang diajukan oleh Molina dan Rao (2010) dengan data aplikasinya adalah data PODES 2008, sebagai peubah penyerta.

\section{HASIL DAN PEMBAHASAN}

Simulasi ini dilakukanuntuk mengevaluasi pengaruh ukuran contoh terhadap perhitungan pendugaan langsung ukuran kemiskinan. Evaluasi dilakukan berdasarkan pada relative bias (RB), absolute relative bias (ARB), dan relative mean square error (RMSE).

\section{Relative Bias (RB).}

Gambar 1 menunjukkan pola fluktuasi positif dan negatif di sekitar nol nilai $\mathrm{RB}$ untuk penduga $\mathrm{P}_{0}, \mathrm{P}_{1}$, dan $\mathrm{P}_{2}$ yang dihasilkan dari sembilan skenario simulasi. Gambar 1 juga memperlihatkan bahwa semakin besar ukuran contoh yang digunakan, nilai $\mathrm{RB}$ untuk $\mathrm{P}_{0}, \mathrm{P}_{1}$, dan $\mathrm{P}_{2}$ yang dihasilkan akan mendekati nilai 0 . Skenario 2,3,4,5,6, 7, 8 dan 9 merupakan skenario dengan nilai RB yang lebih dekat dengan nol jika dibandingkan dengan 
skenario 1. Nilai RB yang dihasilkan

skenario 1 mendekati nol ketika ukuran

contohnya besar $(n=300)$.

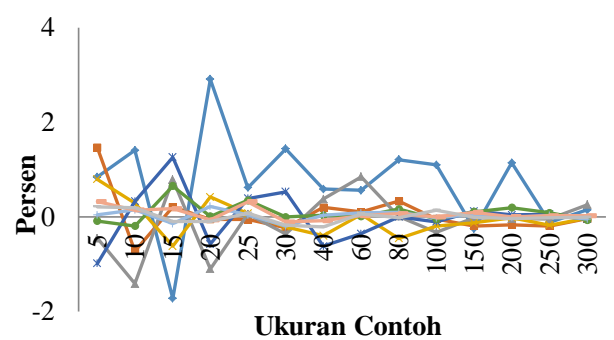

(a)

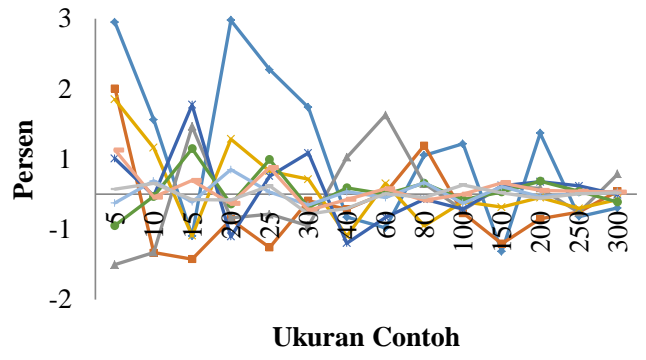

(b)

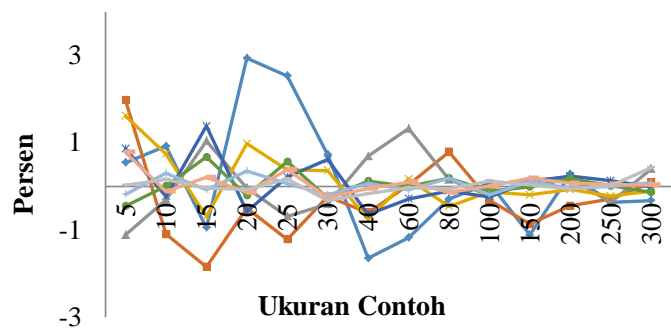

(c)

Keterangan :
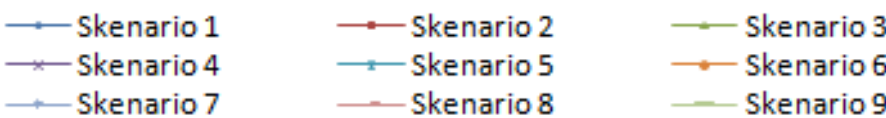

Gambar 1. Plot ukuran evaluasi Relative Bias (RB) metode penduga langsung ukuran kemiskinan moneter hasil simulasi vs ukuran contoh yang digunakan: (a) $\mathrm{P}_{0}$, (b) $\mathrm{P}_{1}$, (c) $\mathrm{P}_{2}$.

\section{Penduga Bayes Empirik Kemiskinan Kecamatan di Kabupaten/Kota Malang}

\section{Absolute Relative Bias (ARB)}

Nilai $\quad A R B \mathrm{P}_{0}, \mathrm{P}_{1}$, dan $\mathrm{P}_{2}$ yang disajikan pada Gambar 2 menunjukkan trend yang cenderung menurun sejalan dengan bertambahnya ukuran contoh dengan pola pergerakan penurunan yang stabil untuk setiap skenario simulasi. Nilai
ARB $\mathrm{P}_{0}, \mathrm{P}_{1}$, dan $\mathrm{P}_{2}$ tertinggi dihasilkan oleh skenario satu pada semua ukuran contoh yang dicobakan. Selain itu, gambar ini juga memperlihatkan bahwa nilai ARB $\mathrm{P}_{0}, \mathrm{P}_{1}$, dan $\mathrm{P}_{2}$ yang dihasilkan oleh skenario sembilan merupakan skenario terbaik, karena pada setiap ukuran contoh nilainya selalu lebih kecil daripada skenario simulasi yang lain. 


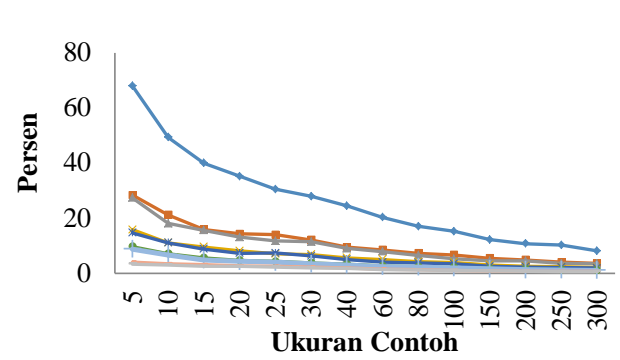

(a)

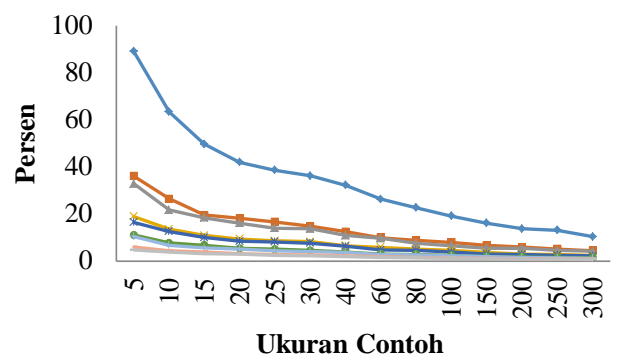

(b)

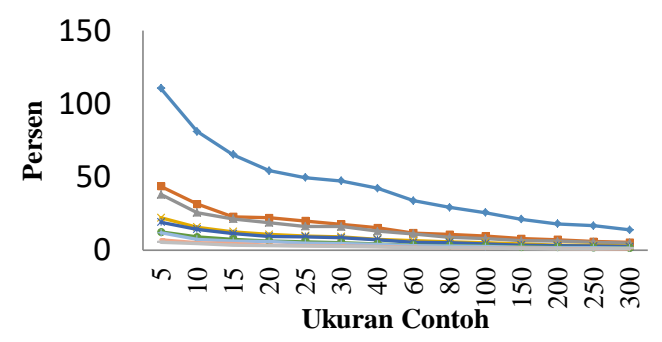

(c)

Keterangan :
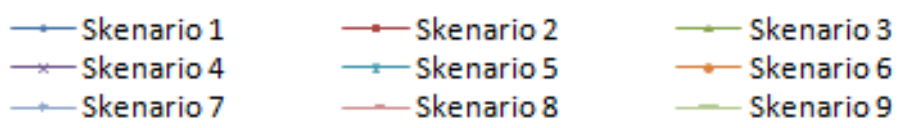

Gambar 2. Plot ukuran evaluasi ARB penduga langsung ukuran kemiskinan moneter hasil simulasi vs ukuran contoh yang digunakan: (a) $\mathrm{P}_{0}$, (b) $\mathrm{P}_{1}$, (c) $\mathrm{P}_{2}$

Salah satu sifat dari penduga parameter adalah konsisten. Suatu penduga dikatakan konsisten apabila nilai dugaan cenderung mendekati nilai parameter untuk $\mathrm{n}$ yang semakin besar atau mendekati tak hingga. Jadi, ukuran contoh yang besar cenderung memberikan penduga yang lebih baik dibandingkan ukuran contoh kecil. Bila ukuran contoh pada subpopulasi kecil bahkan nol maka statistik dari pendugaan langsung akan memiliki ragam galat yang besar bahkan pendugaan tidak dapat dilakukan (Rao, 2003).

Hal ini sejalan dengan hasil simulasi yang telah dilakukan, yaitu semakin besar ukuran contoh maka bias yang dihasilkan akan semakin kecil. Sebaliknya, semakin kecil ukuran contoh yang digunakan, maka bias yang dihasilkan akan semakin besar.

\section{Relative Mean Square Error (RMSE)}

Gambar 3 menyajikan hasil nilai RMSE untuk $\mathrm{P}_{0}, \mathrm{P}_{1}$, dan $\mathrm{P}_{2}$ dari sembilan skenario. Gambar 3 memperlihatkan adanya pergerakan penurunan nilai RMSE $\mathrm{P}_{0}, \mathrm{P}_{1}$, dan $\mathrm{P}_{2}$ yang stabil seiring bertambahnya jumlah ukuran contoh yang digunakan. Nilai

RMSE $\mathrm{P}_{0}, \mathrm{P}_{1}$, dan $\mathrm{P}_{2}$ yang dihasilkan berbanding terbalik dengan ukuran contoh yang digunakan. Semakin besar ukuran contoh yang digunakan, maka semakin kecil nilai RMSE $\mathrm{P}_{0}, \mathrm{P}_{1}$, dan $\mathrm{P}_{2}$ yang dihasilkan atau nilainya mendekati nol. Hal ini terlihat dari nilai RMSE yang dihasilkan untuk setiap skenario. Nilai RMSE $\mathrm{P}_{0}, \mathrm{P}_{1}$, dan $\mathrm{P}_{2}$ yang tertinggi terdapat di skenario 1 dengan $n=5$ dan yang terendah terdapat di skenario 9 
dengan $\mathrm{n}=300$. Artinya bahwa ketika range data penelitian besar untuk ukuran contoh yang kecil, nilai RMSE yang dihasilkan akan besar. Begitupun sebaliknya, jika menggunakan ukuran contoh yang besar pada range data yang besar, nilai RMSE yang dihasilkan kecil.

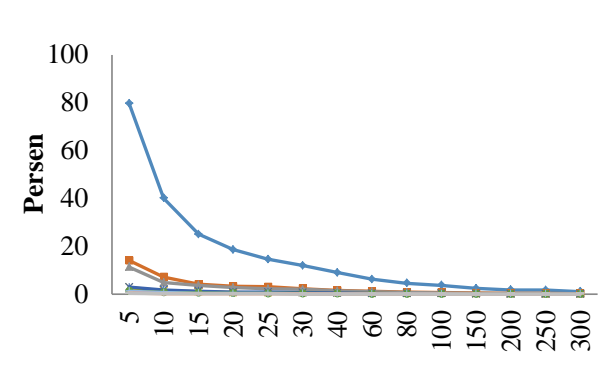

Ukuran Contoh

(a)

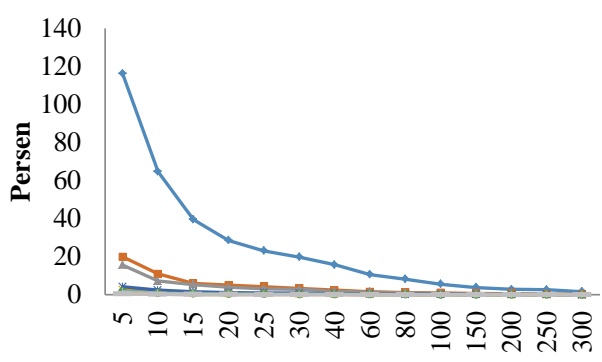

Ukuran Contoh

(b)

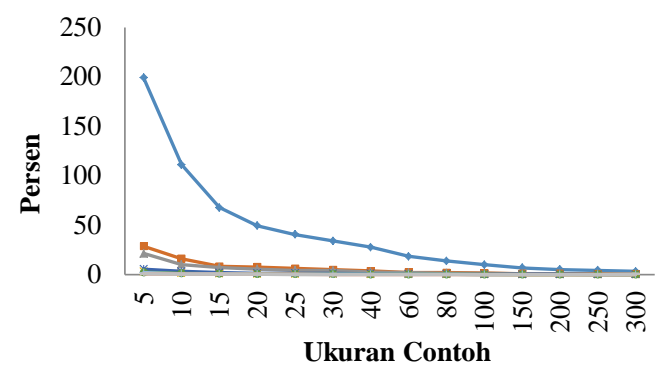

(c)

Keterangan :

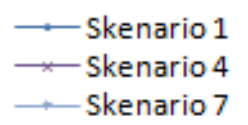

$$
\begin{array}{r}
\longrightarrow \text { Skenario } 2 \\
\longrightarrow \text { Skenario } 5 \\
- \text { Skenario } 8
\end{array}
$$$$
\text { - Skenario } 3
$$$$
\longrightarrow \text { Skenario } 6
$$$$
\text { - Skenario } 9
$$

Gambar 3. Plot ukuran evaluasi RMSE pendugaan langsung ukuran kemiskinan moneter hasil simulasi vs ukuran contoh yang digunakan: (a) $\mathrm{P}_{0}$, (b) $\mathrm{P}_{1}$, (c) $\mathrm{P}_{2}$

Suatu penduga yang baik memiliki sifat Mean Square Error (MSE) dengan ragam dan bias yang kecil. Untuk menemukan pendugaan dengan sifat MSE yang baik, perlu dicari penduga yang mengontrol ragam dan bias. Pada beberapa kasus tertentu, ada perpotongan antara ragam dengan biasnya yaitu kenaikan kecil dari bias akan menyebabkan penurunan nilai ragam, sehingga akan menghasilkan kenaikan nilai MSE (Casella dan Berger, 2002 :330).

\section{Contoh Terapan}

\section{Eksplorasi Data}

Eksplorasi data dilakukan terhadap data pengeluaran per kapita dari tiap kabupaten di Propinsi Jawa Timur. Pengeluaran per kapita rumah tangga per bulan di Provinsi Jawa Timur sangat beragam yang ditunjukkan oleh simpangan baku sebesar Rp.291.371. Kabupaten Trenggalek memilki pengeluaran per kapita per bulan paling kecil (Rp. 41.350) dan Kota Surabaya memiliki pengeluaran per kapita per bulan penduduk sebesar Rp.5.442.241. Deskriptif statistik 
pengeluaran perkapita per bulan penduduk Provinsi Jawa Timur dapat dilihat pada tabel 2.

Tabel 2. Deskriptif Statistik Pengeluaran Per kapita per bulan Rumah Tangga

\begin{tabular}{lc}
\hline Statistik & Pengeluaran per Kapita \\
\hline Rata-Rata & 337.106 \\
Simpangan & \\
Baku & 291.371 \\
Minimum & 41.350 \\
Maksimum & 5.442 .241 \\
\hline
\end{tabular}

Pola sebaran log normal mengakomodir bentuk dari karakteristik pengeluaran per kapita di Provinsi Jawa Timur yaitu bernilai positif, memiliki ekor yang cenderung menjulur ke kanan dan pengeluaran yang mengumpul disisi kiri. Selain itu, pola datanya bersifat cenderung mengelompok di suatu nilai dan terlihat ada beberapa rumah tangga memiliki pengeluaran per kapita yang jauh melebihi rata-rata pengeluaran perkapita rumah tangga. Histogram sebaran data pengeluaran per kapita per bulan rumah tangga dapat dilihat pada gambar 4 .

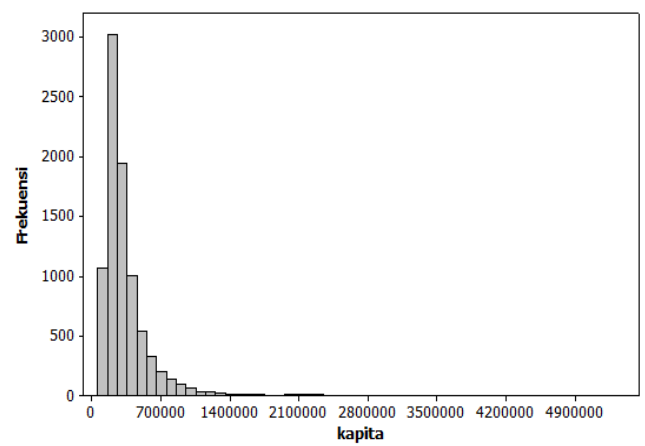

Gambar 4. Histogram Pengeluaran perkapita

\section{Evaluasi Pendugaan Langsung Ukuran Kemiskinan Moneter Tingkat Kabupaten/Kota di Provinsi Jawa Timur}

Hasil pendugaan langsung ukuran kemiskinan moneter untuk tingkat kabupaten/kota di Propinsi Jawa Timur disajikan pada Tabel 3. Kabupaten Probolinggo memiliki nilai $\mathrm{P}_{0}$ yang tertinggi sebesar $45 \%$ dan juga nilai $\mathrm{P}_{1}$ yang tertinggi, $11 \%$. Adapun nilai $\mathrm{P}_{2}$ tertinggi yaitu sebesar 3,9\% terdapat pada kabupaten Bangkalan. Lebih lanjut, untuk nilai $\mathrm{P}_{0}, \mathrm{P}_{1}$, dan $\mathrm{P}_{2}$ yang terendah terdapat pada Kota Surabaya, dengan masingmasing pendugaan nilai ukuran kemiskinannya yaitu sebesar 9,3\%, 1,4\%, dan $0,3 \%$.

Metode pendugaan yang digunakan oleh BPS untuk data Susenas adalah metode pendugaan langsung yaitu metode pendugaan yang didasarkan pada data yang diperoleh dari suatu proses penarikan contoh di suatu area tertentu. Metode pendugaannya semata-mata didasarkan pada metode penarikan contoh yang digunakan.

Hasil pendugaan langsung yang disajikan pada tabel 3, menunjukkan bahwa untuk ukuran contoh rumah tangga yang kecil bisa tidak diperoleh hasil nilai dugaan ukuran kemiskinan moneter (nilai pendugaannya nol). Hal ini karena pendugaan langsung pada subpopulasi relatif tidak memiliki presisi yang memadai karena kecilnya jumlah contoh yang digunakan untuk memperoleh dugaan tersebut. Hasil yang diperoleh dari pendugaan langsung memberikan gambaran bahwa pada wilayah dengan ukuran contoh kecil dapat menghasilkan pendugaan yang tidak akurat. Suatu wilayah sangat tidak mungkin nilai persentase penduduk miskinnya bernilai nol. 
Nurul Hidayati, Asep Saefuddin, dan Anang Kurnia : Analisis Pendugaan Ukuran Kemiskinan Moneter Pada Contoh Berukuran Kecil

FIBONACCI : Jurnal Pendidikan Matematika dan Matematika. Vol. 5 (1), pp: 37 - 54.

Tabel 3.Jumlah Rumah Tangga dan Nilai Penduga Langsung Ukuran Kemiskinan Moneter Tingkat Kabupaten/Kota di Provinsi Jawa Timur dalam persen (\%)

\begin{tabular}{|c|c|c|c|c|c|}
\hline Kode Kab/kota & Nama Kab/Kota & Jumlah RT & $\mathbf{P}_{\mathbf{0}}$ & $\mathbf{P}_{1}$ & $\mathbf{P}_{2}$ \\
\hline 3576 & Kota Mojokerto & 22 & 00,0 & 0,0 & 0,0 \\
\hline 3572 & Kota Blitar & 32 & 00,0 & 0,0 & 0,0 \\
\hline 3574 & Kota Probolinggo & 37 & 33,4 & 6,8 & 2,4 \\
\hline 3575 & Kota Pasuruan & 47 & 19,5 & 3,7 & 0,8 \\
\hline 3577 & Kota Madiun & 48 & 23,2 & 3,4 & 0,8 \\
\hline 3579 & Kota Batu & 48 & 20,5 & 4,4 & 1,5 \\
\hline 3571 & Kota Kediri & 74 & 27,5 & 5,5 & 1,5 \\
\hline 3501 & Kab. Pacitan & 123 & 24,0 & 4,5 & 1,4 \\
\hline 3519 & Kab.Madiun & 154 & 17,1 & 3,7 & 1,1 \\
\hline 3503 & Kab.Trenggalek & 156 & 17,3 & 5,5 & 2,6 \\
\hline 3512 & Kab.Situbondo & 156 & 33,8 & 7,6 & 2,2 \\
\hline 3520 & Kab.Magetan & 158 & 20,5 & 3,2 & 0,9 \\
\hline 3511 & Kab.Bondowoso & 173 & 26,8 & 5,8 & 1,6 \\
\hline 3528 & Kab.Pamekasan & 173 & 30,1 & 6,1 & 1,7 \\
\hline 3526 & Kab.Bangkalan & 184 & 41,9 & 11,0 & 3,9 \\
\hline 3573 & Kota Malang & 190 & 10,0 & 1,9 & 0,6 \\
\hline 3527 & Kab.Sampang & 191 & 21,1 & 3,5 & 1,0 \\
\hline 3521 & Kab.Ngawi & 201 & 19,3 & 2,9 & 0,7 \\
\hline 3502 & Kab. Ponorogo & 207 & 18,1 & 2,6 & 0,6 \\
\hline 3516 & Kab.Mojokerto & 222 & 13,0 & 2,4 & 0,6 \\
\hline 3518 & Kab.Nganjuk & 234 & 17,4 & 2,5 & 0,5 \\
\hline 3508 & Kab.Lumajang & 235 & 20,8 & 3,5 & 0,8 \\
\hline 3504 & Kab. Tulungagung & 238 & 10,5 & 1,8 & 0,5 \\
\hline 3523 & Kab.Tuban & 249 & 18,3 & 3,1 & 0,7 \\
\hline 3525 & Kab.Gresik & 249 & 37,3 & 8,7 & 2,8 \\
\hline 3529 & Kab.Sumenep & 250 & 33,0 & 6,4 & 1,7 \\
\hline 3513 & Kab.Purbolinggo & 252 & 45,2 & 9,6 & 2,8 \\
\hline 3505 & Kab. Blitar & 265 & 12,4 & 1,9 & 0,5 \\
\hline 3522 & Kab.Bojonegoro & 268 & 14,7 & 2,3 & 0,6 \\
\hline 3517 & Kab.Jombang & 285 & 20,6 & 2,8 & 0,6 \\
\hline 3524 & Kab.Lamongan & 286 & 14,3 & 2,3 & 0,5 \\
\hline 3514 & Kab.Pasuruan & 342 & 26,6 & 5,8 & 1,8 \\
\hline 3506 & Kab. Kediri & 350 & 33,2 & 6,2 & 1,8 \\
\hline 3510 & Kab. Banyuwangi & 379 & 15,4 & 2,4 & 0,6 \\
\hline 3515 & Kab.Sidoardjo & 398 & 11,4 & 2,0 & 0,5 \\
\hline 3509 & Kab.Jember & 549 & 31,5 & 5,5 & 1,5 \\
\hline 3507 & Kab.Malang & 578 & 27,1 & 5,4 & 1,5 \\
\hline 3578 & Kota Surabaya & 604 & 09,3 & 1,4 & 0,3 \\
\hline
\end{tabular}

\section{Evaluasi Penduga Langsung Ukuran Kemiskinan Moneter Tingkat Kecamatan di Kabupaten dan Kota Malang}

Penduga langsung ukuran kemiskinan dan pendugaan Bayes empirik untuk setiap kecamatan di Kabupaten dan Kota Malang disajikan pada gambar 5 dan tabel 4. Dapat dilihat bahwa Kecamatan Pakis, Pagak, dan Purjon merupakan tiga kecamatan yang mempunyai indeks kemiskinan tertinggi di
Kabupaten Malang. Hal ini dapat dilihat dari nilai $\mathrm{P}_{0}, \mathrm{P}_{1}$, dan $\mathrm{P}_{2}$. Kecamatan Pakis mempunyai nilai $\mathrm{P}_{0}$ tertinggi yaitu sebesar $56,25 \%$, Kecamatan Pagak mempunyai nilai P1 tertinggi yaitu sebesar $11,09 \%$, dan Kecamatan Purjon mempunyai nilai P2 tertinggi yaitu sebesar 3,58\%. Kecamatan Dau, Klojen, dan Lowokwaru mempunyai indeks kemiskinan yang rendah. Hal ini dapat dilihat dari nilai $\mathrm{P}_{0}, \mathrm{P}_{1}$, dan $\mathrm{P}_{2}$ yang mencapai nilai $0 \%$. Pendugaan langsung ini 
mempunyai berbagai kelemahan, salah satunya yaitu ukuran contoh. Jika ukuran contoh kecil maka akan cenderung mempunyai tingkat akurasi dugaan yang rendah, artinya meskipun sifat dari pendugaan ini tidak bias tetapi mempunyai ragam yang besar. Hal ini didukung oleh hasil simulasi seperti pembahasan di atas. Solusi untuk mengatasi permasalahan ini yaitu dengan pendugaan Bayes.

Pada tabel 4, dengan metode pendugaan Bayes dapat dilihat bahwa Kecamatan Singosari merupakan kecamatan termiskin di Kabupaten Malang. Hal ini dapat dilihat dari nilai $\mathrm{P}_{0}, \mathrm{P}_{1}$, dan $\mathrm{P}_{2}$ berturut-turut yaitu $38,11 \%, 13,54 \%$, dan $6,58 \%$. Kecamatan Sukun merupakan kecamatan termiskin di Kota Malang. Hal ini dapat dilihat dari nilai $\mathrm{P}_{0}, \mathrm{P}_{1}$, dan $\mathrm{P}_{2}$ berturut-turut yaitu $32,21 \%, 10,87 \%$, dan $5,10 \%$. Kecamatan Dau, Klojen, dan Lowokwaru mempunyai indeks kemiskinan yang rendah atau dapat dikatakan penduduknya makmur. Hasil ini cukup berbeda dengan pendugaan langsung. Kecamatan Dau menjadi kecamatan termakmur karena mempunyai nilai indeks kemiskinan $\mathrm{P}_{0}, \mathrm{P}_{1}$, dan $\mathrm{P}_{2}$ terendah, yaitu $4,68 \%, \quad 1,12 \%, \quad$ dan $0,41 \%$.

Tabel 4. Penduga Langsung Ukuran Kemiskinan dan Pendugaan Bayes Empirik untuk Setiap Kecamatan di Kabupaten/Kota Malang dalam persen (\%)

\begin{tabular}{lrrrrrrr}
\hline \multirow{2}{*}{ Nama Kab/Kota } & \multirow{2}{*}{$\begin{array}{c}\text { Jumlah } \\
\text { RT }\end{array}$} & \multicolumn{2}{c}{ Pendugaan Langsung } & \multicolumn{3}{c}{ Bayes Empirik } \\
\cline { 3 - 8 } & & \multicolumn{1}{c}{$\mathbf{P}_{\mathbf{0}}$} & \multicolumn{1}{c}{$\mathbf{P}_{\mathbf{1}}$} & $\mathbf{P}_{\mathbf{2}}$ & $\mathbf{P}_{\mathbf{0}}$ & $\mathbf{P}_{\mathbf{1}}$ & $\mathbf{P}_{\mathbf{2}}$ \\
\hline Kab.Malang & & & & & & & \\
Donomulyo & 16 & 25,00 & 5,21 & 1,15 & 23,04 & 7,20 & 3,20 \\
Kalipare & 16 & 12,50 & 0,84 & 0,06 & 13,92 & 3,92 & 1,62 \\
Pagak & 15 & 40,00 & 11,09 & 3,50 & 26,28 & 8,48 & 3,86 \\
Bantur & 32 & 18,75 & 4,10 & 1,21 & 26,93 & 8,67 & 3,94 \\
Gedangan & 16 & 12,50 & 0,71 & 0,06 & 16,06 & 4,64 & 1,96 \\
Sumbermanjing & 16 & 12,50 & 1,43 & 0,19 & 16,34 & 4,74 & 2,00 \\
Dampit & 30 & 40,00 & 6,67 & 1,90 & 22,39 & 6,89 & 3,03 \\
Tirtoyudo & 16 & 18,75 & 3,93 & 1,13 & 15,50 & 4,44 & 1,86 \\
Ampelgading & 15 & 33,33 & 3,71 & 0,58 & 22,65 & 7,04 & 3,12 \\
Poncokusumo & 16 & 18,75 & 2,31 & 0,48 & 21,71 & 6,68 & 2,95 \\
Wajak & 32 & 37,50 & 7,44 & 2,18 & 25,15 & 7,96 & 3,57 \\
Turen & 15 & 13,33 & 2,26 & 0,60 & 18,49 & 5,50 & 2,37 \\
Bululawang & 31 & 22,58 & 5,74 & 1,80 & 27,16 & 8,76 & 3,98 \\
Gandanglegi & 16 & 31,25 & 5,14 & 1,03 & 19,40 & 5,82 & 2,52 \\
Kepanjen & 32 & 3,13 & 0,59 & 0,11 & 14,52 & 4,09 & 1,69 \\
Sumberpucung & 16 & 50,00 & 8,38 & 1,85 & 33,84 & 11,67 & 5,56 \\
Ngajum & 16 & 31,25 & 5,61 & 1,61 & 22,84 & 7,09 & 3,14 \\
Wonosari & 16 & 31,25 & 7,12 & 1,82 & 22,45 & 6,96 & 3,08 \\
Wagir & 16 & 12,50 & 2,55 & 0,67 & 24,43 & 7,73 & 3,48 \\
Pakisaji & 32 & 25,00 & 6,85 & 2,25 & 15,93 & 4,57 & 1,91 \\
Tajinan & 16 & 25,00 & 5,76 & 1,61 & 28,76 & 9,48 & 4,38 \\
Tiumpang & 15 & 20,00 & 3,59 & 0,89 & 23,00 & 7,16 & 3,18 \\
Pakis & 16 & 56,25 & 10,92 & 2,64 & 25,11 & 7,99 & 3,60 \\
Lawang & 16 & 6,25 & 0,23 & 0,01 & 24,27 & 7,66 & 3,44 \\
Singosarin & 45 & 24,44 & 3,21 & 0,66 & 38,11 & 13,54 & 6,58 \\
Karangploso & 15 & 20,00 & 4,61 & 1,19 & 14,44 & 4,09 & 1,70 \\
Dau & $\mathbf{1 5}$ & 0,00 & 0,00 & 0,00 & 4,68 & 1,12 & 0,41 \\
Purjon & 14 & 35,71 & 9,06 & 3,58 & 22,96 & 7,18 & 3,20 \\
& & & & & & &
\end{tabular}


Nurul Hidayati, Asep Saefuddin, dan Anang Kurnia : Analisis Pendugaan Ukuran Kemiskinan Moneter Pada Contoh Berukuran Kecil

FIBONACCI : Jurnal Pendidikan Matematika dan Matematika. Vol. 5 (1), pp: 37 - 54.

\begin{tabular}{lcccccrr}
\hline \multirow{2}{*}{ Nama Kab/Kota } & \multirow{2}{*}{\begin{tabular}{c}
\multirow{2}{*}{$\mathbf{R T}$} \\
\end{tabular}} & \multicolumn{2}{c}{ Pendugaan Langsung } & \multicolumn{3}{c}{ Bayes Empirik } \\
\cline { 3 - 8 } & & \multicolumn{1}{c}{$\mathbf{P}_{\mathbf{0}}$} & $\mathbf{P}_{\mathbf{1}}$ & $\mathbf{P}_{\mathbf{2}}$ & $\mathbf{P}_{\mathbf{0}}$ & $\mathbf{P}_{\mathbf{1}}$ & $\mathbf{P}_{\mathbf{2}}$ \\
\hline Ngantang & 16 & 37,50 & 7,31 & 2,62 & 23,73 & 7,46 & 3,34 \\
Kota Malang & & & & & & & \\
Kedungkandang & 48 & 20,83 & 3,47 & 0,96 & 27,60 & 8,92 & 4,06 \\
Sukun & 48 & 10,42 & 1,92 & 0,70 & 32,21 & 10,87 & 5,10 \\
Klojen & $\mathbf{1 6}$ & 0,00 & 0,00 & 0,00 & 13,58 & 3,81 & 1,57 \\
Blimbing & 31 & 9,68 & 1,38 & 0,22 & 13,46 & 3,74 & 1,53 \\
Lowokwaru & $\mathbf{4 7}$ & 0,00 & 0,00 & 0,00 & 15,54 & 4,43 & 1,84 \\
\hline
\end{tabular}

Hasil pendugaan langsung cenderung lebih kecil dari pendugaan Bayes. Hal ini dapat digambarkan pada gambar 5. Hasil ini sebagai bahan kajian bahwa tingkat kemiskinan di setiap kecamatan
Kabupaten/Kota Malang masih tinggi. Hal ini dkarenakan setiap kecamatan tampak makmur (hasil pendugaan langsung), padahal penduduk di Kabupaten/Kota Malang masih miskin.

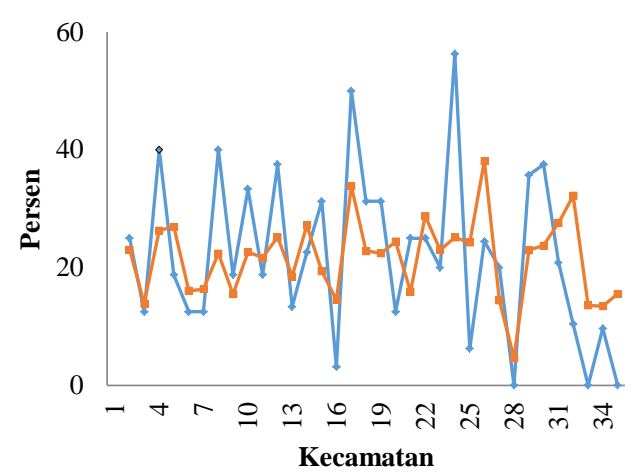

(a)

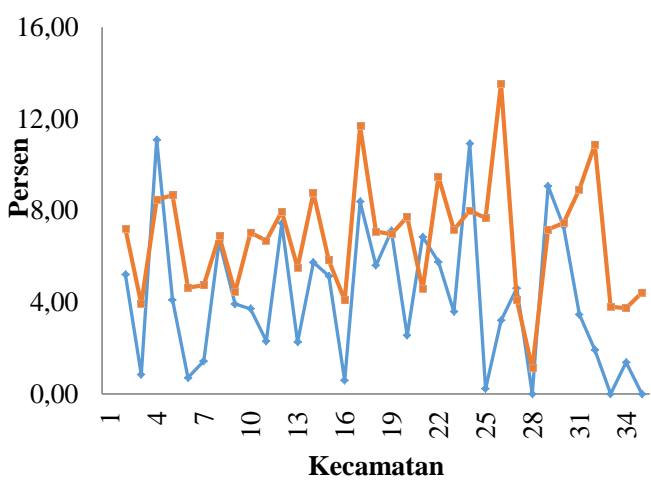

(b)

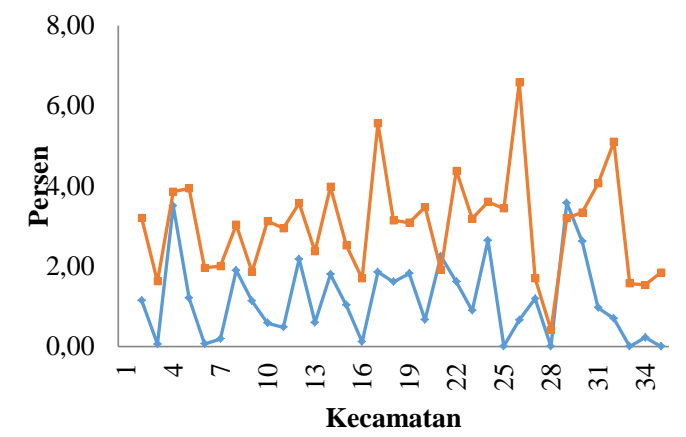

Keterangan :

(c)

\section{$\longrightarrow$ Pendugaan Langsung P2 $\rightarrow$ Bayes Empirik P2}

Gambar 5. Penduga Langsung Ukuran Kemiskinan dan Pendugaan Bayes Empirik Untuk Setiap Kecamatan di Kabupaten dan Kota Malang: (a) $P_{0}$, (b) $P_{1}$, (c) $P_{2}$. 
Indikator-indikator kemiskinan $\left(\mathrm{P}_{0}\right.$, $\mathrm{P}_{1}$, dan $\mathrm{P}_{2}$ ) ini mempunyai hubungan yang kuat. Hal ini dibuktikan dengan hasil dari nilai korelasi antara $\mathrm{P}_{0}, \mathrm{P}_{1}$, dan $\mathrm{P}_{2}$ pada Kabupaten dan Kota Malang yang mendekati satu dan bernilai positif.

Berdasarkan data persentase penduduk miskin yang diperoleh dari pendugaan langsung dan metode Bayes Emprik, maka masing-masing daerah kecamatan di Kabupaten dan Kota Malang dapat dibagi menjadi tiga kriteria. Kriteria tersebutdidasarkan atas tiga interval yaitu 1) persentase penduduk miskin lebih dari $18,5 \%$ tergolong tinggi, 2) persentase penduduk miskin $15,4 \%$ sampai dengan $18,5 \%$ tergolong sedang, dan 3) persentase penduduk miskin kurangdari $15,4 \%$ tergolong rendah. Skala interval diperoleh berdasarkan persentase penduduk miskin tingkat propinsi Jawa Timur (18,5\%) dan nasional $(15,4 \%)$.

Gambar 6a menyajikan persentase penduduk miskin untuk setiap kecamatan di Kabupaten Malang dengan menggunakan metode pendugaan langsung. Gambar 6a memperlihatkan bahwa daerah yang mempunyai persentase penduduk miskin yang tergolong tinggi ada dua puluh satu daerah kecamatan, yaitu: Donomulyo,
Pagak, Bantur, Dampit, Tirtoyodo, Ampelgading, Poncokusumo, Bululawang, Gandanglegi, Sumberpucung, Ngajum, Wonosari, Pakisaji, Tajman, Tiumpang, Pakis, Singosari, Karangploso, Purjon, dan Ngantang. Sedangkan daerah yang persentase penduduk miskinnya tergolong rendah ada delapan kecamatan, yaitu: Kalipare, Gedangan, Sumbermanjing, Turen, Kepanjen, Wagir, Lawang, dan Dau.

Persentase penduduk miskin untuk setiap kecamatan di Kabupaten Malang dengan metode Bayes Empirik yang disajikan pada gambar $6 \mathrm{~b}$ menunjukkan bahwa persentase penduduk miskin yang tergolong tinggi ada dua puluh daerah kecamatan, yaitu: Donomulyo, Pagak, Bantur, Dampit, Ampelgading, Poncokusumo, Wajak, Bululawang, Gandanglegi, Sumberpucung, Nagjum, Wonosari, Wagir, Tajinan, Tiumpang, Pakis, Lawang, Singosari, Purjon, dan Ngantang. Daerah yang tergolong sedang berdasarkan persentase penduduk miskinnya ada lima kecamatan, yaitu Gedangan, Sumbermanjing, Tirtoyudo, Turen, dan Pakisaji. Sedangakan daerah yang persesntase penduduk miskinnya rendah ada empat kecamatan, yaitu Kalipare, Kepanjen, Karangploso, dan Dau. 


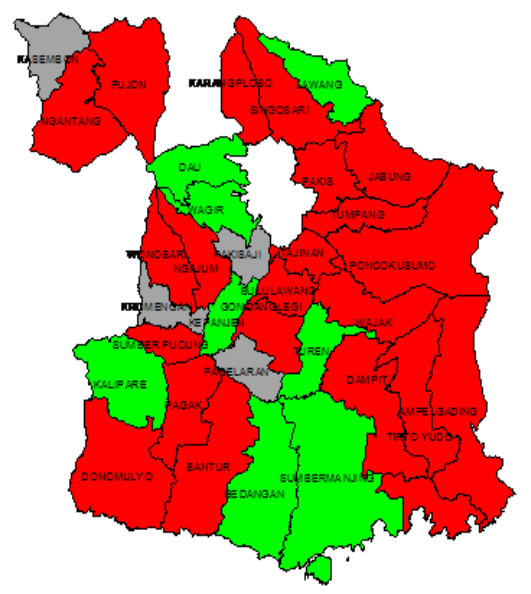

(a)

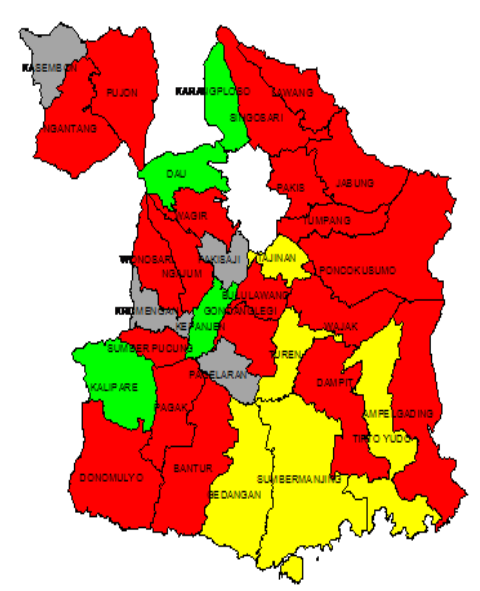

(b)

Keterangan :

$\square$ Rendah $\square$ Sedang $\square$ Tinggi $\square$ Bukan Sampel

Gambar 6. Peta Kabupaten Malang Berdasarkan Persentase Penduduk Miskin:

(a) Pendugaan Langsung, (b) Bayes Empirik

Gambaran daerah kecamatan di Kota Malang dengan menggunakan metode pendugaan langsung dan Bayes empirik berdasarkan persentase penduduk miskin disajikan pada Gambar 7. Pada Gambar 7a dapat dilihat bahwa persentase penduduk miskin yang tergolong tinggi ada empat daerah, yaitu Kecamatan Sukun, Klojen, Bimbing, dan Lowokwaru. Daerah yang tergolong rendah persentase penduduk miskinnya, yaitu Kecamatan Kedungkandang.

Berdasarkan Gambar 7b, persentase penduduk miskin yang tergolong tinggi ada dua daerah, yaitu Kecamatan Klojen dan Bimbing. Daerah yang persentase penduduk miskinnya tergolong sedang yaitu Kecamatan Lowokwaru. Sedangkan daerah yang persentase penduduk miskinnya tergolong rendah adalah kecamatan Kedungkandang dan Sukun.

Dari Gambar 6 dan 7, dapat dilihat perbedaan hasil secara kasat mata dari metode pendugaan langsung dan Bayes empirik. Kabupaten Malang pada pendugaan langsung dan Bayes empirik ada tiga kecamatan yang mengalami penurunan peringkat tingkat kemiskinan, sedangkan untuk sembilan kecamatan yang lain mengalami kenaikan peringkat tingkat kemiskinan. Kecamatan di Kota Malang juga mengalami perubahan peringkat tingkat kemiskinan. Ada tiga kecamatan yang mengalami kenaikan peringkat tingkat kemiskinan, sedangkan kecamatan yang lain mengalami penurunan peringkat tingkat kemiskinan. 


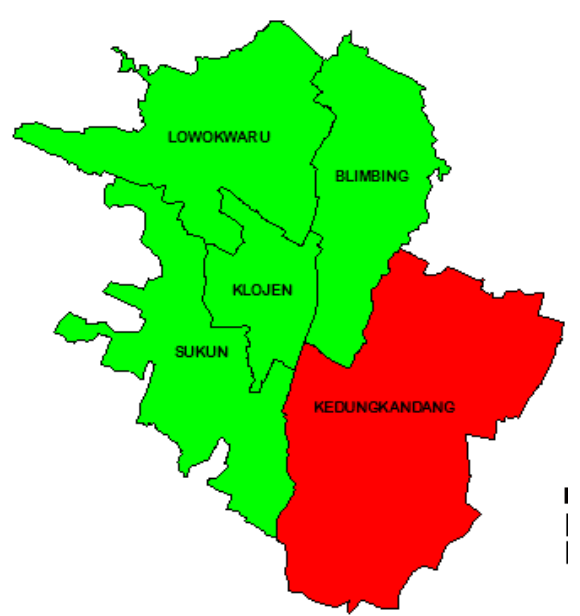

(a)

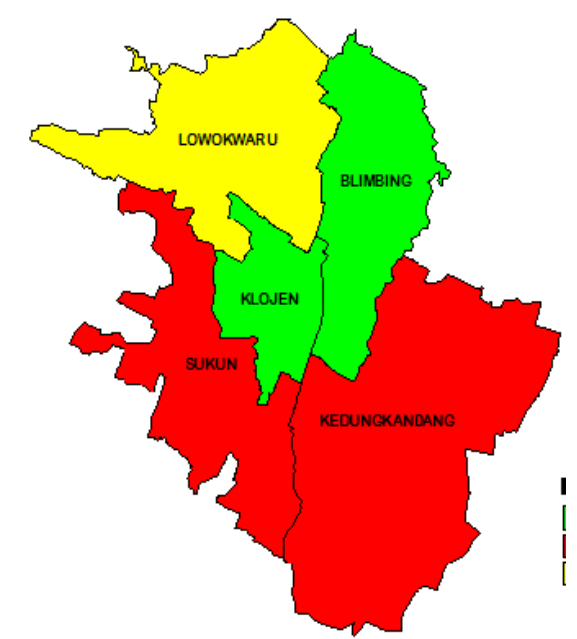

(b)

Keterangan :
$\square$ Rendah
$\square$ Sedang
Tinggi
Bukan Sampel

Gambar 7. Peta Kota Malang Berdasarkan Persentase Penduduk Miskin:

(a) Pendugaan Langsung, (b) Bayes Empirik

Perubahan peringkat tingkat khususnya dalam pendugaan langsung. Jika kemiskinan yang ditunjukkan pada gambar 6 dan 7 ini, menunjukkan bahwa metode pendugaan langsung dapat dikoreksi dengan metode Bayes empirik, karena memberikan hasil pendugaan yang akurat, ditunjukkan dengan ragam yang kecil dan dapat menduga titik yang tidak tersampel dengan memanfaatkan kekuaatan area sekitarnya

\section{SIMPULAN}

Ukuran contoh dalam statistik
memegang peranan penting dalam
menentukan akurasi dan presisi pendugaan,

\section{UCAPAN TERIMA KASIH}

Peneliti mengucapkan terimakasih kepada Badan Pusat Statistik (BPS) yang telah membantu peneliti dalam menyediakan data yang digunakan untuk kepentingan penelitian.

\section{DAFTAR PUSTAKA}

Abdillah, R. 2011. Pengelompokkan Kabupten/Kota Berdasarkan Ukuran Kemiskinan Moneter dan Nonmoneter di Jawa Tengah Tahun 2008. Skripsi tidak diterbitkan. Jakarata :Sekolah Tinggi Ilmu Statistik. 
Nurul Hidayati, Asep Saefuddin, dan Anang Kurnia : Analisis Pendugaan Ukuran Kemiskinan Moneter Pada Contoh Berukuran Kecil

FIBONACCI : Jurnal Pendidikan Matematika dan Matematika. Vol. 5 (1), pp: 37 - 54.

BPS. 2008. Analisis dan Penghitungan Tingkat Kemiskinan 2008. Jakarta : Badan Pusat Statistik.

Casella, G \& Berger, RL. 2002. Statistical Inference. California : Duxbury.

Elbers, C., Lanjouw, J. O. and Lanjouw, P. 2003. Micro-level Estimation of Poverty and Inequality. Econometrica, Vol. 71 (1), pp: 355-364.

Foster J, Greer J and Thorbecke E. 1984. A Class of Decomposable Poverty Measures. Econometrica, Vol. 52 (3), pp: 761-766.

Haslett JS, Isidro CM, and Jones G. 2010. Comparison of Survey regression Techniques In The Context Of Small Area Estimation of Poverty, Vol. 36 (2), pp: 157-170.

Mafruhah I. 2009. Multidimensi Kemiskinan. Surakarta: LPP dan UNS Press.

Molina I, Rao, JNK. 2010. Small Area Estimation of Poverty Indicators. The Canadian Journal Statistics. Vol.38 (3), pp: 369-385.

Rao, JNK. 2003. Small Area Estimation. New York : John Willey \& Sons.

Rozuli, AI. 2012. Menakar Program-Program Penanggulangan Kemiskinan dan Upaya Pembangunan Berkelanjutan. [online] Tersedia: http://www.infid.org/wpcontent/uploads/2012/05/Poverty-Reduction-Imron-Rozuli-FISIB-UB-Malang.pdf. [08 Mei 2012].

Saei A, Chambers R. 2003. Small Area Estimation : A Review of Methods Based on The Application of Mixed Model. University of Southampton : S3RI Methodology Working Paper M30/16. [online] Tersedia: http://siteresources.worldbank.org/PGLP/Resources/200709gv-03povertymeasurement.pdf. 
FIBONACCI : Jurnal Pendidikan Matematika dan Matematika

Volume 5 No. 1 Bulan Juni Tahun 2019 